\title{
油浸絶縁流動系における光学的電界測定と電荷挙動
}

\begin{tabular}{|c|c|c|c|c|c|}
\hline 学生員 & 羽 & 柴 & 靖 & 人* & (名古屋大学) \\
\hline 正員 & 加 & 藤 & 克 & 巳 & (名古屋大学) \\
\hline & 仲 & 神 & 芳 & 武 & 官機総合研究 \\
\hline & & 本 & 昌 & 広 & 棇合研究 \\
\hline & & & & 仁 & 胥大学) \\
\hline
\end{tabular}

\section{Optical Measurement of Electric Field and Charge Behavior Induced by Flow Electrification in Oil Immersed Insulating System}

\author{
Yasuhito Hashiba* ,Student member, Katsumi Kato, Member, \\ \# Yoshitake Nakagami, Member, ${ }^{\#}$ Masahiro Miyamoto, Member, Hitoshi Okubo, Member \\ (Nagoya University, ${ }^{\#}$ Fuji Electric Corporate Research and Development, Ltd.)
}

\begin{abstract}
In this paper, we carried out an optical measurement of electric field in transformer oil by using Kerr effect to discuss electric field and charge behavior in transformer oil induced by flow electrification. We constructed a system which consisted of electro-optic field measurement part and an oil flowing part. By using this system, we measured electric field in charged transformer oil. When charged oil flew into the measurement system without voltage application, electric field appeared in the oil. Particularly, when a pressboard was placed in the field measurement system, electric field appeared strongly because of charge accumulation on the pressboard. We discussed experimental results from the viewpoints of leakage current and the time constant of electric field relaxation in equivalent circuit. Finally, we investigated charge behavior in flowing transformer oil, and proposed a model which could explain charge behavior associated with the flow electrification.
\end{abstract}

キーワード：カー効果, 流動帯電, 変圧器油, プレスボード

(Kerr effect, Flow electrification, Transformer oil, Pressboard)

\section{1.まえがき}

電力用変压器の内部絶縁は, 変圧器油とプレスボード等 による複合絶縁系によって構成されている. 変圧器油は， 絶縁と同時に機器を冷却する冷新としての機能も兼权て抢 り, 冷却効率を向上させるため変压器内部を強制循環当れ ている。このとき変圧器油がブレスボード上を流動するこ とによって，液体と固体の界面において静電気的な帯電， いわゆる流動帯電が発生する。このような帯電は機器内部 の電界分布を変歪させたり，絶縁性能を低下させることが 考えられ，以前から絶縁上の問題となっている。この流動 带電に対しては，油の流動装置からの漏九電流を計測した

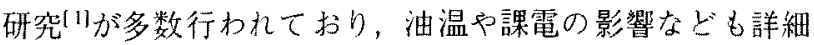
に検討さ㞦ている2[2].しかし，油流動時の油中電界の測定 に基づく電荷挙動に関するる研究はほとんど行われていない.

変压器油中の電界分布を直接測定する手法として, 電気 光学力一効果を用いた電界測定法 ${ }^{[3-4]}$ が開発されている.
この電界測定法に扔いては，カー効果を用いることにより， 非接触かつ高精度に電界分布を測定することが可能となっ ておりこれまでにも様々な液体誘電体中に扔ける電界測 定例が報告されている，今回我々は，カー効果による光学 的電界測定法を用い，流動している変圧器油の油中電界を 直接測定した。また，測定結果をもとに油流動時の油中電 荷の挙動について考察したので報告する。

\section{2. 実験方法}

\section{1 電気光学カー効果による電界測定法}

電気光学カ一効果による電界測定法に扔いては，液体誘 電体に光を透過させた場合の出射光の位相差が電界強度に よって変化する現象を応用し, 出射光強度を測定すること によって電界強度を求める。图1にカー効果を用いた電界 測定装置を示す。なお，変圧器油のカー定数は常温におい て3.53 $\times 10^{-15}\left[\mathrm{~m} / \mathrm{V}^{2}\right]$ と非常に小さいため，本測定において 
はカー効果に電界変調と入射円偏光を組み合わせることに よって測定感度を向上させている。テストセルは，内部に 平行平板電極 (真鍮製， $65 \mathrm{~mm} \times 100 \mathrm{~mm}$ ，ギャップ長 $10 \mathrm{~mm}$ ）を配置した後密封し，水分や酸素による油の劣化 を防ぐために真空ポンプで十分に脱気した後，油面上の空 間に乾燥窒素を大気圧まで封入した。

電界測定においては，下部電極に電界変調のため振幅 $200 \mathrm{~V}$ ，周波数 $1 \mathrm{kHz}$ の交流電圧を重睤して行った。レーザの 光源は出力 $7 \mathrm{~mW}$ ，波長632.8nmの $\mathrm{HeNe}$ ーザを用いた.レー ザは偏光子，4分の1波長板を通過することによって円偏光 となりこの状態でテストセルに入射した．

テストセル内の変圧器油中の電界によってレーザには位 相差が生じる。この位相差を含んた出射光は，検光子拉上

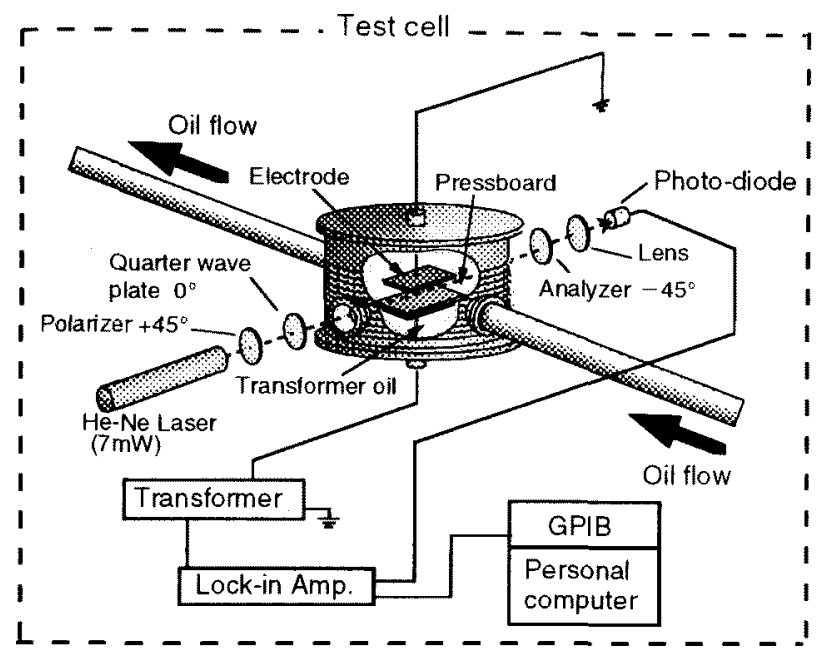

図1 カー効果を用いた油中電界測定装置

Fig. 1 Experimental setup for electric field measurement in transformer oil using Kerr effect.
びレンズを通過して，フォトダイオードにおいて検出した． 出射光強度はロックインアンプに扔いて変調周波数で同期 検波し，これをもとに電界强度を求め大。な抢，図1に示 した電界測定系に扔ける測定感度は0.1 kV/ $/ \mathrm{cm}$ ある。.また， 最短5秒間隔で電界の測定を連続して行うことができ，油 中電界の時間变化を高時間分解能で測定することができる。

\section{2 変圧器油の流動装置}

図2に上述の電界測定系を含めた油流動系の装置を示寸。 同図中のポンブによって変圧器油は流動し, 装置内部を循 環する。このポンプでは回転数を変化させることによって 流量を調節できる。 今回, 変圧器油は流量 $3.5 \ell / \mathrm{min}$ から 14.0 $\ell / \min$ の範囲で流動させた。油の流量は, オーバル式の流量 計を用いて測定した。油はいったん緩和タンクに送り込ま れた後，带電発生部内を流動する。带電発生部の内部には セルロース製のフィルタが配置してある。油がこのフィル

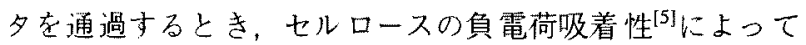
油中に帯電が発生する。この帯電した油をテストセルに導 入した，なお油の流動は，带電発生部内を流動させること によって油中に帯電が発生する場合上，带電発生部をバイ バスさせて油中に帯電が発生しない場合の二通り行うこと ができる。

それぞれの場合についてテストセル中の平行平板電極の 中央に扔ける油中電界を2。1節で述べたカー効果による 電界測定法を用いて測定した。变圧器油の流動㧍よび油中 電界の測定は全て室温で行った。

また，図2の変圧器油の流動装置においては，水分計扔 よび温度計を接続した。 导らに, 変圧器油の体積抵抗率を 測定するための電極毛組み込んだ。これにより，油の抵抗 率や水分率の測定と油中電界の測定の同時測定を可能とし ている.

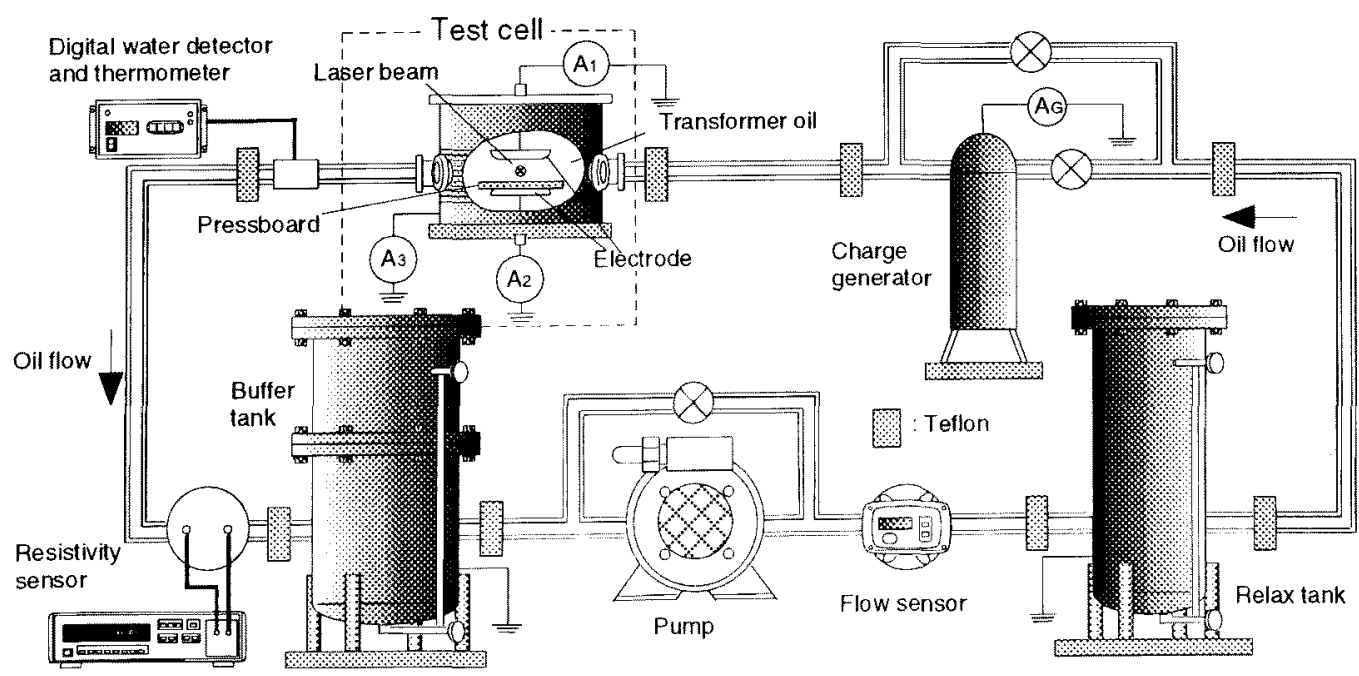

図2 電界測定系を含め大油流動系の装置

Fig.2 Experimental setup for flow electrification and electric field measurement. 


\section{3. 実験結果および検討}

\section{1 变圧器油を流動させた場合の油中電界測定}

まず，テスト七ル中の平行平板電極の下部電極上に厚さ $1 \mathrm{~mm}$ のプレスボードを配置した。なお，平行平板電極には 電压を印加せず，接地とした，図2の流動装置において， 带電発生部を通して油を流動导せることで油を带電させた。 変圧器油は10分間流動させ，その後流動を停止した。この ときの流動中及び流動停止後の変圧器油の油中電界を上述 の電極系においてカー効果を用いた手法により測定した。 なお油中電界の測定点は，上部電極加ら4.5mm下方の箇所 とした，測定結果を図3に示す。同図より，変圧器油が流 動することによって帯電した場合，課電尚れていない変生 器油中に電界が発生することがわかる。この油中電界は流 動開始と同時に発生し，時間の経過とともに增加して約 $0.8 \mathrm{kV} / \mathrm{cm}$ で飽和する傾向があることがわかる.

また，変圧器油を流動させる場合の流量について，14.0 $\ell / \mathrm{min}, 10.6 \ell / \mathrm{min}, 7.1 \% / \mathrm{min}$ 抢よび $3.5 \% / \mathrm{min}$ と変化させて同粎 の電界測定を行ったが，流量が多いほど電界の増加および 飽和に详する時間が早いことがわかる。たたし，流量3.5 l $\min$ で変圧器油を流動させた場合については流量が小さい ため，他の場合に比較して小さい油中電界となっている。

一方，流動停止後の油中電界の変化については，流量 $3.5 \ell$ $\min$ で変压器油を流動尚せた場合を除いて，流動時の流量 にかかわらず約 $0.8 \mathrm{kV} / \mathrm{cm}$ あった電界が流動停止後約 10 分間 で測定感度以下まで減衰している。なお，因引に扔ける電 界減衰の時定数は135秒であった。

次に，比較のために，流動に上って带電した油中の電界 をブレスボードを配置しない平行平板電極間において測定

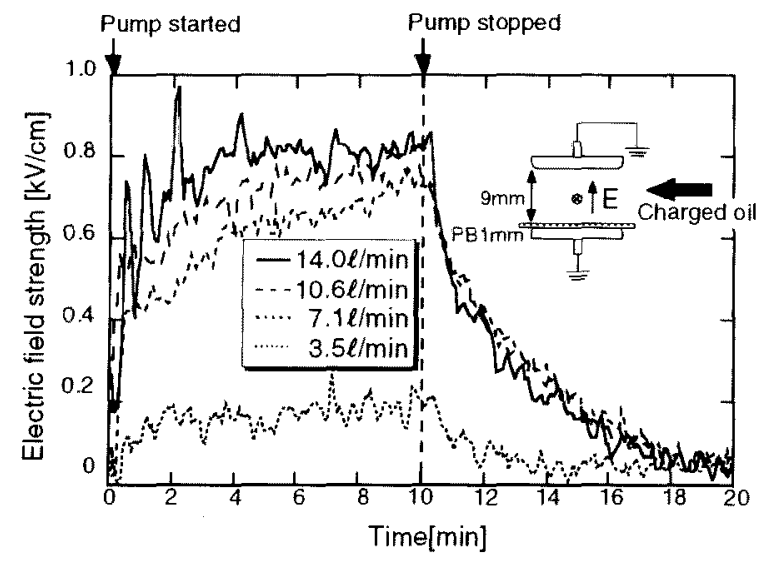

図3ブレスボードを下部電極上に配置した場合の， 带電した変圧器油流動時の油中電界とその流量依存性

Fig. 3 Flow rate dependence of electric field strength in transformer oil/PB composite system with charge generator.

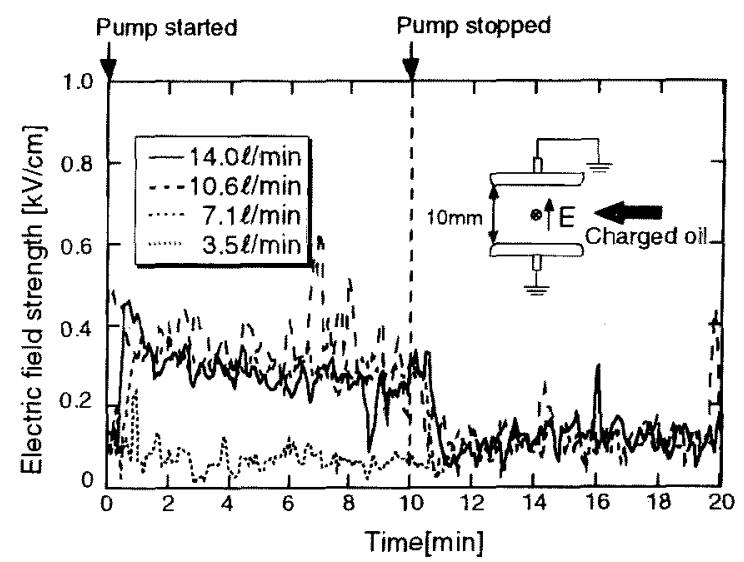

図4 プレスボードを配置しない場合の，帯電した 変圧器油流動時の油中電界とその流量依存性

Fig.4 Flow rate dependence of electric field strength in transformer oil with charge generator.

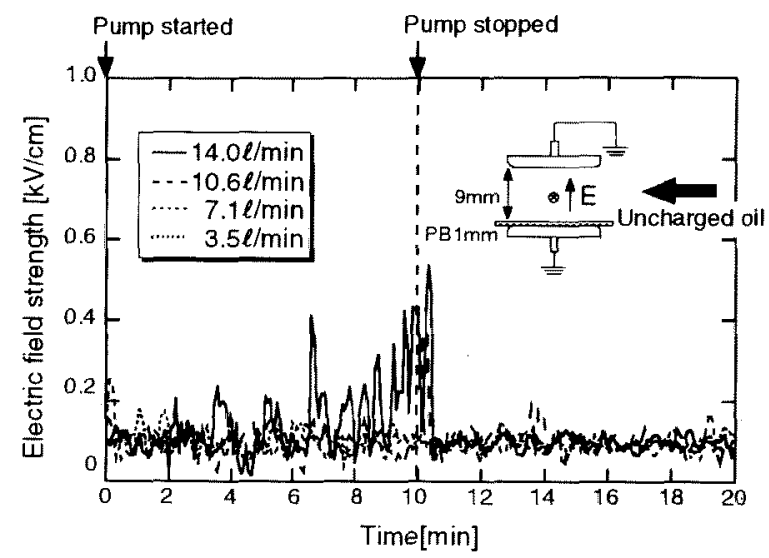

园5ブレスボードを下部電極上に配置した場合の，

带電しない変王器油流動時の油中電界とその流量依存性

Fig.5 Flow rate dependence of electric field strength in transformer oil/PB composite system without charge generator.

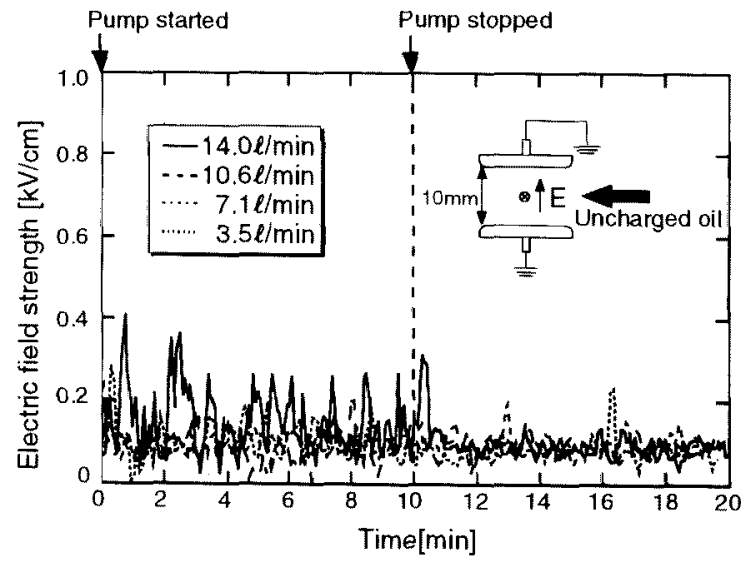

図6ブレスボードを配置しない場合の，带電しない 変压器油流動時の油中電界とその流量依存性

Fig.6 Flow rate dependence of electric field strength in transformer oil without charge generator. 
した。この場合の油中電界の測定結果を図4に示す。同図 より，図3と同様に，流動開始とともに油中に電界が発生 していることがわかる。しかし，変压器油の流動を続けて も油中電界は增加せず，流量によらずほほ $0.4 \mathrm{kV} / \mathrm{cm}$ 一定の 大きさを保っている，流動停止後については，約1分で測 定感度以下まで急激に減衰した。

一方, 带電発生部をバイパスして変圧器油を流動芑せ油 中に带電が発生しない場合について油流動時の油中電界の 測定を行った。測定結果を図5揖よび図6に示す，図5がプ レスボードを配置した電極系に扔ける油中電界測定結果で, 図6がプレスボードを配置しない電極系における油中電界 測定結果である。雨図に抽て, 変圧器油の流量㧈よび電 極上に拉忛るプレスボードの有無にかかからず，油中に帯 電電荷がない場合は油中電界は発生せず，油の流動によっ てレーザ光が散乱学れることに起因すると思われる信号お よび測定系の持つばらつきが测定されているのみである。 図3と図5，および図4と図6 比較することにより，油流動 時の油中電界の発生は, 油中の帯電の有無によって決まり, 油の流動そのものが油中電界に及ぼす影響は充分小さいこ とがわかった。

\section{2 油流動時における油中電荷挙動}

図3拉よび図4において示したように，帯電発生部内走通 して変圧器油を流動させ油が带電した場合，課電されてい ない変圧器油中に電界が発生した。この電界測定結果をも とに，油が帯電した場合における油中の電荷挙動について 考察を行った。

本研究においては, 変压器油を帯電発生部内のセルロー ス製のフィル夕を通過させて流動导せることにより，油中 に带電を発生させた。セルロースの表面は正に分極した水 素原子に覃われているため, 変压器油がこの表面上を流動 すると油中の負電荷がセルロース表面に吸着され，油は正 に带電すると考えられる。そこで, 油中の带電の極性を確 認するために，带電発生部からの漏れ電流 $\mathrm{AG}$ ，電界測定を 行うテスト七ル中の電極およびテスト七ル本体からの漏れ 電流 $\mathrm{A1} ， \mathrm{~A} 2 ， \mathrm{~A} 3$ ，その他の部位加らの漏れ電流 $\mathrm{A} 4$ の測定 を行った。漏九電流の测定系を図7に示し，図7に対する測 定結果を表に示した。同表より, 变圧器油が流動した場 合，带電発生部からは負の漏れ電流が，電極，テストセル およびその他の部位からは正の漏れ電流が測定され，その 総和はほほ零となり，この流動系における電流の収支が理 解できる。この結果より，带電発生部内のセルロース製フィ ルタに油中の負電荷が吸着され, 残りの正電荷がテスト七 ルまで流入したと考兵られる。この正電荷の流入によって 油中に電界が発生したと考无られる。帛の後, 油中の正電 荷は，他の配管や調整タンク部などから緩和してゆくもの と考之られる。

图8には，プレスボードを下部電極上に配置した電極系
における油流動時の油中電荷挙動のモデル図示し，これ を用いて図30油中電界測定結果に対する検討を行う。図8 (a)において，油中の正電荷は下部電極上に配置されている プレスボード上に蓄積してゆきここの電荷の蓄積によって 油中電界は増加する。このプレスボードへの電荷の蓄積は やがて飽和する。同図(b)のように，プレスボードへの電荷 蓄積の飽和によって, 油中電界の増加も飽和する。油中電 界飽和時におけねでレスボード上の蓄積電荷密度は, $\rho=\varepsilon E$ より約 $1.5 \mu \mathrm{C} / \mathrm{m}^{2}$ と求められた。流動停止後については，新 たな電荷の供給が無くなるため，同図(c)のようにプレスボー ド上に蓄積していた電荷は油中へと緩和してゆく。この蓄 積電荷の緩和現象に起因して，油中電界も緩やかに減衰し ていると考えられる。

図9にー、ブレスボードを配置しない電極系に扔りる油 流動時の油中電荷举動のモデル図を示し，これを用いて図 4の油中電界測定結果に対寸る検討を行う。同図(a)に扔い て带電した変圧器油が流入することによって，油中に電界 が発生する。しかし，プレスボードが電極上に存在しない ため，同図(b)のように流動を続けても電極間に招ける油中 の電荷密度は増加せず, 油中電界はほぼ一定の值となる。 流動停止とともに油中に電荷が供給されなくなり，同図(c) のように電極間の電荷密度は急激に減少する。このため， 流動停止後の油中電界も急激に減衰していると考之られる。 以上のように，図8および図9のような電荷挙動を考えるこ とによって，油流動時の油中電界の变化を説明することが できた。次節では，電界测定結果に対する定量的な娭討を 行う。

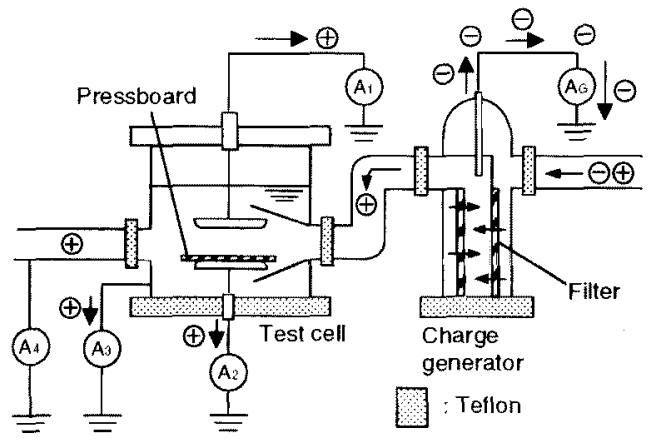

図7 流動装置加らの漏れ電流測定系

Fig. 7 Leakage current from experimental setup.

表1图7に扔ける漏れ電流測定結果

Table 1 Leakage current at Fig.7.

\begin{tabular}{|c|c||c|c|c|c|}
\hline Flow rate & $\mathrm{AG}(\mathrm{nA})$ & $\mathrm{A} 1(\mathrm{nA})$ & $\mathrm{A} 2(\mathrm{nA})$ & $\mathrm{A} 3(\mathrm{nA})$ & $\mathrm{A} 4(\mathrm{nA})$ \\
\hline $3.5 \ell / \mathrm{min}$ & -49 & 3 & 3 & 14 & 23 \\
\hline $7.1 \ell / \mathrm{min}$ & -96 & 10 & 10 & 45 & 24 \\
\hline $10.6 \ell / \mathrm{min}$ & -126 & 10 & 10 & 33 & 43 \\
\hline $14.0 \ell / \mathrm{min}$ & -140 & 10 & 10 & 40 & 55 \\
\hline
\end{tabular}



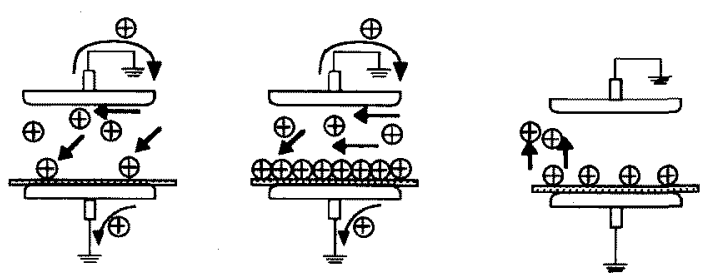

(a) Charging. (b) Charge accumulation. (c) Slow relaxation.

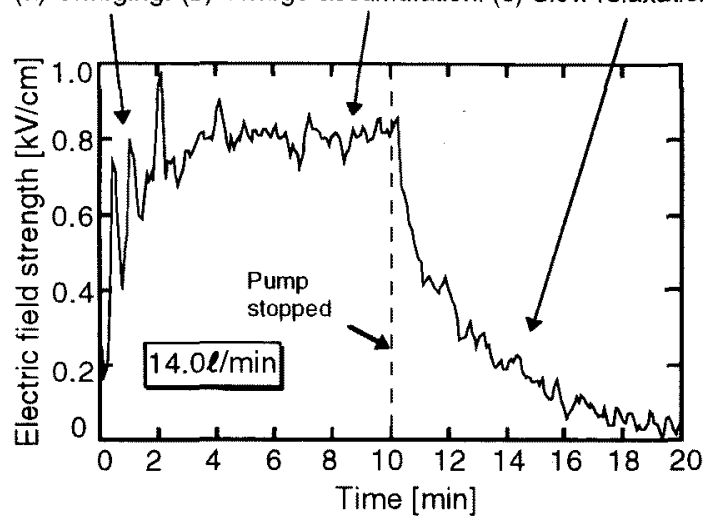

図8 図30油中電界と電荷举動

Fig. 8 Schematic illustration of charge behavior and time dependence of electric field in oil /PB composite, system in Fig.3.

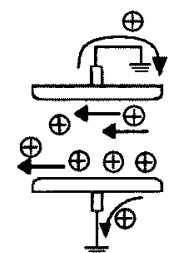

(a) Charged oil flow in.

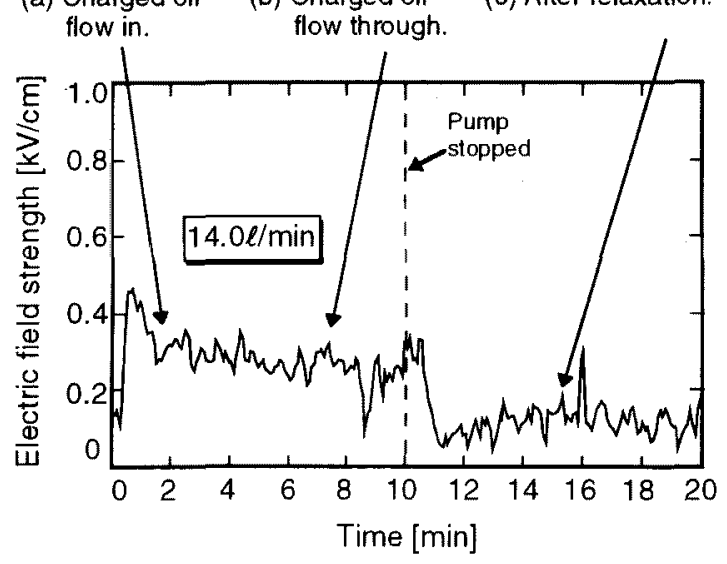

図9図4の油中電界と電荷挙動

Fig. 9 Schematic illustration of charge behavior and time dependence of electric field in oil in Fig.4.

\section{3 電界隇衰の時定数}

今回電界測定に扔いて用いた電極系は，図10(a)に示すよ うに電極および変圧器油，プレスボードによって構成され る複合絶縁系である、これを誘電体のCR等価回路を用いる と，図10(b)のような電気回路に置き換えて考えることがで きる. 同図(b)において, 変圧器油が流動しているときはス イッチが閉じ，ここからプレスボード上に電荷が供給され る。一方，流動停止後については，スイッチが開放となり， プレスボード上に蓄積した電荷は緩和してゆくと考える. 同図(b)より，今回の測定に用いた電極系に拐ける電荷の緩 和の時定数 $て$ は

$$
\tau=\frac{\left(C_{o i l}+C_{P B}\right) R_{o i l} R_{P B}}{R_{o i l}+R_{P B}}=\frac{\varepsilon_{\text {oil }} d_{P B}+\varepsilon_{P B} d_{\text {oil }}}{\sigma_{\text {oil }} d_{P B}+\sigma_{P B} d_{o i l}}
$$

で与えられる。ここで， $\sigma_{\mathrm{o} 11}$ と $\sigma_{\mathrm{PB}}$ とはそれぞれ変圧器油と プレスボードの導電率を示し， $\mathrm{d}_{\mathrm{oil}}$ と $\mathrm{d}_{\mathrm{PB}}$ とはギキップ長を 示している。

ここで図3の測定結果に扔いて，流動停止後の電界減衰 の時定数は135秒であった。これを(1)式に代入し，导らに， 変圧器油とプレスボードの導電率の比について, $\sigma_{\mathrm{PB}} /$ $\sigma_{\text {oi }}=100$ と仮定して ${ }^{[6]}$ 計算を行った。その結果, 変圧器油の 導電率は $\sigma_{\mathrm{oi} i}=2.5 \times 10^{-14} \mathrm{~S} / \mathrm{cm}$ なり，この逆数より，体積抵 抗率は $4.0 \times 10^{13} \Omega \mathrm{cm}$ と求められた。一方, 変圧器油の体積 抵抗率については直接測定も行った。流動装置に組み込ん た液体電極を用いて変圧器油に直流電圧 $100 \mathrm{~V}$ を印加し，電 圧印加1分後の值を測定した結果，体積抵抗率は3.6 $\times 10^{13} \Omega$ $\mathrm{cm}$ と测定された。才なわち，誘電体のCR等価回路を用い て計算によって求めた変圧器油の体積抵抗率は，直接測定 によって求めた值とほほ一致し, 両者とも変圧器油の体積 抵抗率として妥当な值であった。このことより，今回测定 した流動停止後の油中電界の減衰は, 油中の電荷挙動に起 因したものであると考えることができる。

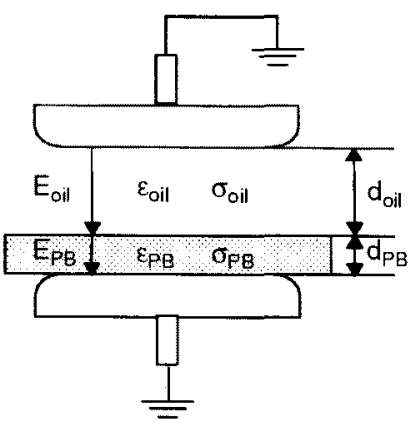

(a) Electrode configuration.

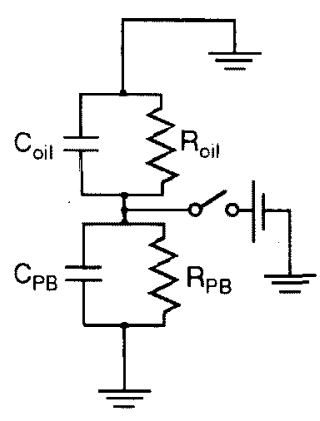

(b) Equivalent circuit.
図10 変圧器油/プレスボード複合絶稼系とCR等価回路

Fig.10 Equivalent circuit of transformer oil / pressboard composite system. 


\section{4.あとがき}

今回, 带電した変圧器油流動時の油中電界を電気光学カー 効果を用いて行う測定系を構築した。この測定系を用いて， 油が流動带電した場合の油中電界の時間変化を測定した。 プレスボードを平行平板電極の下部電極上に配置した場合 と配置しない場合を対象として, 油中電界の流量依存性に ついても調べた。 その結果, 以下のことが明らかになった。

(1) 帯電発生部内のセルロース製フィル夕を通して変圧器 油を流動させた場合, 変圧器油中に带電が生じる。こ の帯電に起因して油中電界が発生する. 特に, 油の流 路にプレスボードが存在する場合, プレスボード上に 電荷が蓄積し, 油中電界がより顕著に発生する。

(2) 変圧器油が帯電していない場合は, 油が流動しても油 中電界は発生しない.

（3）油中の電荷挙動モデルに基づいて油流動時の油中電界 の発生および減衰が説明できた。

(4) 誘電体のCR等価回路と流動停止後の電界減衰の時定数 を用いて, 変圧器油の体積抵抗率を算出した。この值 は実測した変圧器油の体積抵抗率とほほ一致した。

これらのことより，カー効果を用いた手法によって，変圧 器油が流動によって帯電した場合の油中電界の測定を行う ことが可能であることを示した.すなわち, 油流動時の油 中電荷の挙動を定量的に把握できることを示した。ここで 得られた知見は, 油流動時の電荷挙動や変圧器内部の絶縁 設計を考えるうえで重要なものと考えられる。

(平成10年10月9日受付，平成11年1月25日再受付)

\section{文献}

[1]吉田, 山地, 畑野, 辻, 長谷川, 細川, 光庵：「直流 油浸絶縁に扔ける流動帯電現象」, 電気学会論文誌 B, 117巻, 6号, pp.806-813, 1997.

[2] 田中, 中越, 畑野, 宮尾, 小島, 古川, 小幡, 門脇 : 「変圧器油の流動帯電特性に及ほす直流電界と直流父 流重睤電界の影響」, 電気学会論文誌A, 118巻, 6号, pp.629-634, 1998.

[3] T.Maeno and T. Takada:"Electric field Measurement in Liquid Dielectrics Using a Combination of ac Voltage Modulation and a Small Retardation Angle", IEEE Trans. on Elect. Insul.,Vol. 22, No. 4, pp.503-509, 1987.

[4] H.Okubo, R.Shimizu, A.Sawada, K.Kato, N.Hayakawa, and M.Hikita: "Kerr Electro-optic Field Measurement and Charge Dynamics in Transformer-oil/Solid Composite Insulation Systems", IEEE Trans. on Diele. and Elect. Insul., Vol. 4. No. 1, pp.64-70, 1997.

[5] 安田, 後藤, 大久保, 月岡, 宮本：「大容量変圧器に
おける流動帯電の一抑制法について」, 電気学会論文 誌B, 105巻, 3号, pp.79-86, 1985.

[6] 斉藤, 武：「電気絶縁紙」, コロナ社, p.329, 1969.
羽柴 靖人
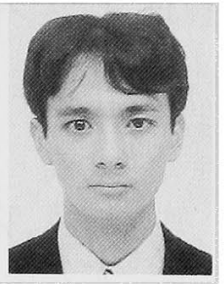

加藤 克巳

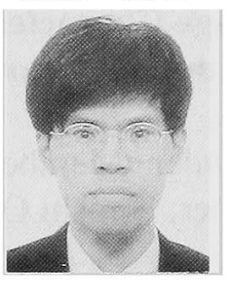

仲神芳武

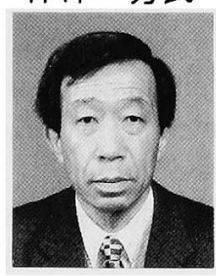

宮本 昌広

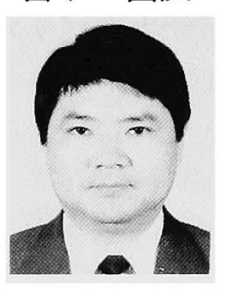

大久保 仁

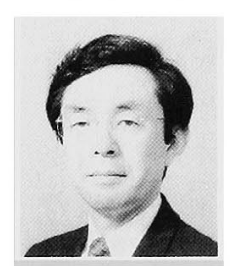

（正員）1969年5月20日生まれ。97年3月 名古屋大学大学院工学研究科博士課程後 期課程修了. 同年4月同大学助手, 現在に 至る. 工学博士. 主として, 高電圧機器 を対象とした電界解析技術および電界最 適化に関する研究に従事.96年電気学会 進歩賞受賞.

（正員）1945年5月15日生まれ。64年3月 松山工業高校電気科卒業. 同年4月富士電 機( 株)入社. 80 年 4 月(株)富士電機総合研 究所出向. 主として電力用変圧器の研究 開発に従事, 現在に至る。

(正員) 1956年7月21日生专れ。79年3月 東北大学電気工学科卒業. 同年 4 月富士 電機(株)入社. 80 年 4 月(株)富士電機総合 研究所出向. 主として大電力変電機器の 研究開発に従事, 現在に至る。

（正員）1948年10月29日生まれ。73年3月 名古屋大学大学院工学研究科博士課程前 期課程修了。同年 4 月(株)東芝入社. 高電 圧技術開発に従事。76年7月～ 78 年2月上 イッ・アーヘン工科大学高電圧研究所㧍 よびミュンヘン工科大学高電圧研究所客 員研究員. 89 年7月名古屋大学工学部電気 学科助教授，91年4月同教授，現在に至る. IEEE, VDE会員. 